\title{
Venous Embolism
}

National Cancer Institute

\section{Source}

National Cancer Institute. Venous Embolism. NCI Thesaurus. Code C111654.

The passage of an embolus from its site of formation to another location within the venous system. 